Athens Journal of History - Volume 6, Issue 3, July 2020 - Pages 175-198

\title{
US-Syrian Relations, 1920-1967: The Bitter Harvest of a Flawed Policy
}

\author{
By Jacob Abadi*
}

\begin{abstract}
This essay explores the course of US-Syrian relations from the end of World War I until the Six Day War of 1967. It argues that despite the early understanding between the two countries the US government never managed to develop a robust foreign policy toward this country and always regarded it as part of greater strategic and ideological concerns, which occupied the minds of the policy makers in Washington at that time such as the competition with the Soviet Union over the Middle East, which loomed large in US defense policy during the Cold War and the struggle against pan-Arabism. In addition, the author attributes this failure to the deference which the US government had toward French interests in the region and to its tendency to regard Syria as a mere participant in the Arab-Israeli conflict and above all, to intervene in Syrian affairs with a deliberate intent to overthrow the regime and install pro-US leaders in Syria. The attempts to interfere in Syria began soon after the country's independence and had a negative effect of the future of the bilateral relations. In addition, the author argues that Syria's leaders tended to rely on Soviet aid and thereby put little efforts in the attempt to convince Washington to adopt a more balanced policy in the Israeli-Syrian conflict. The author shows how the flawed foundations of the bilateral relations culminated in the hostility which brought Syria to sever it relations in the aftermath of the Six Day War of 1967.
\end{abstract}

\section{Introduction}

US relations with Syria underwent numerous twists and turns over the years. Proclaimed in January 1918, President Woodrow Wilson's Fourteen Points called for self-determination for the territories controlled by the former colonial powers and thereby instilled hopes among the Syrian nationalists that an alliance with the US would have a salutary impact on their country. The subsequent imposition of the French mandate on Syria in 1920 and the violent encounter that ensued, intensified their desire for such alliance. In September 1944, the US recognized Syria's independence and diplomatic relations were established the following month. The bilateral relations remained cordial until the late 1940s, when the US intervened in an effort to install the Syrian military leader Hosni al-Za'im who seemed more willing to collaborate with the West than the Nationalist Party that ruled the country. The bilateral relations deteriorated following the rise of Egyptian president Gamal Abd al-Nasser in 1954, but it was not until the formation of the UAR (United Arab Republic) between Egypt and Syria in 1958 that Washington severed its relations with

*Professor of History, United States Air Force Academy, USA. 
Damascus. The diplomatic relations were restored after the dissolution of the UAR in 1961 however, they remained cold, there was little commercial or cultural exchange, and Washington did little to promote the ties. Distrust in Syria's aim was common among US officials who were accustomed to regard it as a Soviet satellite. Moreover, the border incidents along the Israeli border led US officials to suspect that Syria was the one that violated the Armistice agreed upon in 1949.

By the mid-1960s the incidents along the border with Israel increased and the Syrians regarded the US as an instigator supporting Israel and its expansionist tendencies. However, the bilateral relations did not reach their nadir until the Six Day War of 1967, when the IDF (Israel Defense Force) managed to defeat Egypt, Syria and Jordan. The war resulted in Israel's conquest of the Golan Heights which Damascus later tried to regain with US pressure but failed. Although the US initiated the peace talks it refrained from pressuring Israel to withdraw and thereby left the Syrian leaders disgruntled. Disgruntled by Washington's attitude the Syrian government severed the diplomatic relations on 6 June, 1967.

This essay concentrates on US-Syrian relations from the end of World War I until the Six Day War and it argues that (a) Despite Syria's initial encouragement the US government had failed to prolong the bilateral relations; (b) The tendency of US officials to regard Syria as a sphere of French influence discouraged them from paying serious attention to it and thereby caused the bilateral relations to deteriorate; (c) Washington's excessive preoccupation with fighting the Cold War and combatting pan-Arabism during the mid-1950s made it practically impossible for its policy makers to differentiate between Egypt and Syria. By regarding both countries as mere Soviet satellites Washington lost the opportunity to explore Syria's unique history and culture and to examine the benefits which close ties with Damascus could bring, and; (d) The linkage which the US government made between its ties with Syria and the IsraeliSyrian conflict made it practically impossible for the bilateral relations to improve.

The essay begins with the initial contacts between the US and Syria starting with President Woodrow Wilson and his vision of friendship with this country. It portrays the views of Syrian nationalists who regarded the US favorably as a result of their bitter experience with the French Mandate imposed on their country in the aftermath of World War I. In addition, it demonstrates how deference toward French interests in that country prevented the US policy makers from fashioning a robust foreign policy toward that country. The second section deals with emergence of the Cold War and it assesses the impact of the race between the two superpowers on US-Syrian relations. It demonstrates the efforts made by Washington to use all the means necessary to reduce Soviet influence in that country, including the covert attempts to overthrow the pro-Soviet leaders in Syria and their dismal failure. 
The last section assesses the negative impact of Washington's attempts to overthrow the Syrian regime on the bilateral relations against the background of the Cold War contest and the clash with pan-Arabism. The sources used in this essay are primary as well as secondary. They include US government and CIA (Central Intelligence Agency) publications, memoirs by leaders and officials who were involved in the contacts with their Syrian counterparts, and articles by commentators and observers.

\section{The Genesis of US-Syria Contacts}

Serious interaction between the US and the Syrian nationalists who aspired to independence did not begin until World War II, which brought the French forces of the pro-Nazi, Vichy regime to that country. Syria was part of the Ottoman Empire until the end of World War I when France was entrusted by the League of Nations to rule the country as a Mandatory power. Nevertheless, the contacts between Syrians and Americans can be traced to the $19^{\text {th }}$ century during which numerous visitors arrived in the country. They included missionaries, merchants and tourists who were generally regarded favorably by the Syrians. For example, an Arab dragoman named Yusef who escorted the Kentucky writer and artist J. Ross Browne in 1853 was recorded to have said, "I have taken a thousand American gentlemen through Syria... Yes Sir...I like the Americans-fun, fight, or frolic."1

The first time Syria's future as an independent state was discussed in Washington was in January 1918, when Wilson proclaimed his Fourteen Points. This document had considerable impact of the proponents of Greater Syria who arrived at the Paris peace conference on January 18, 1919, and claimed that all territories which constituted the Ottoman province of Syria ought to become independent. Prince Faisal, son of Sharif Hussein of Mecca who led the delegation rejected the French demand to control Syria as a mandate and condemned the Balfour Declaration which Britain gave the Jews of Palestine in 1917. However, neither France nor Britain were willing to yield to the nationalists' demands and both insisted on acting as mandatory powers entrusted to rule these areas until their populations become mature enough for independence. When Wilson's suggestion that a commission consisting of representatives of all victorious powers go to Syria and Lebanon to determine the wishes of the population did not materialize, only two of his envoys, Henry King and Charles R. Crane were sent for that purpose. The overwhelming response of the Syrian population was that the US ought to become their

1. Cited in, Michael B. Oren, Power, Faith and Fantasy: America in the Middle East 1776 to the Present (New York: W.W. Norton, 2007), 160. 
mandatory power and if that did not materialize, they would accept a British mandate, but definitely not French.

Many Syrians saw the US as a better alternative to France and Britain. This was largely because the US had no imperial record and its contacts were limited to a few companies which operated in that region. The two key figures who promoted the idea of rapprochement with the US were the Syrian nationalists Fares al-Khoury and Abdul Rahman Shahbandar. According the Khoury, Wilson told Faisal, "if the people truly want independence, then I will not allow any country in the world to control Syria!" 2 But when the issue was discussed again, another nationalist, Shukri al-Quwatli told Crane to inform Wilson that while the Syrians considered the US a friend they will not accept it as a mandatory power. He said explicitly, "we will not move from one disaster to another." 3

Despite his sympathy toward the Arabs, Wilson had little regard toward their aspirations and the region was hardly considered important for the US until oil became an important factor in its foreign policy considerations. The Druze rebellion of 1925 was the first event that led the US government to be interested in Syria. This was largely because the French bombing that ensued hit the properties of US companies in Syria. This event led to tension with France and increased Washington's interest in Syria but when the US entered the Great Depression, little attention was given to that country. However, the region's oil resources and the fact that Syria's independence loomed in the horizon brought the two sides to interact once more. Besides, American culture, which manifested itself in the production of numerous movies and popular songs turned the US into a land of opportunity and freedom in the eyes of many young Syrians. Thus, the firm foundations laid by the US in the Wilsonian age provided a fertile ground for renewed interaction between the two sides. Nevertheless, Syria remained marginal on US foreign policy agenda and it was always dealt with in connection with larger issues such as the Cold War and the rise of pan-Arabism which began playing a significant role in Washington's policy toward that region.

Hoping to protect US interests the State Department began drafting a treaty with Syria and Lebanon in 1938. However, when France began delaying the withdrawal process the State Department came to a decision that signing such treaty was immature and abandoned the idea altogether. ${ }^{4}$ By the beginning of World War II the US government started paying more attention to Syria. The fall of France brought Syria to Washington's attention when the

2. Cited in, Sami Moubayed, Syria and the USA: Washington's Relations with Damascus from Wilson to Eisenhower (London: I.B. Tauris \& Co. Ltd., 2012), 14.

3. Moubayed's interview with Munir al-Ajlani, April 10, 1999. Cited, Ibid, 16.

4. John A. Denovo, American Interests in the Middle East (Minneapolis, Minnesota: University of Minnesota Press, 1963), 336-337. 
war between the forces of Free France and Vichy France spread to the region. In addition, Britain's Prime Minister Winston Churchill's assurance to President Franklin D. Roosevelt on June 7, 1941 that "We have no political interests at all in Syria, except to win the war" reassured the US government that it had a carte blanche to intervene. ${ }^{5}$ No such assurance came from General Charles de Gaulle who led the forces of Free France. US officials were cognizant that the Levant was a French territory but as leading members of the Allies they regarded themselves entitled to deal with Syria at least as long as the war lasted. Nevertheless, during 1939-1942 the State Department kept a low profile in the discussion regarding the Levant and its main purpose was to define the status of that region as non-belligerent in order to justify US shipments of small arms, which it claimed were destined for local purchase and not for assisting the Allies. However, by late 1942, it became clear that the country was unlikely to fall into Axis hands. Consequently, the State Department reverted to insisting on an open-door policy for the Allies in that region. At the same time, however, the State Department was cautious not to antagonize the Vichy regime and did not yield to pressure by the Syrian nationalists to recognize their demand for independence. ${ }^{6}$ Consul General Cornelius van Engert was among several officials who advocated noninterventionist approach, and when the State Department discussed the possibility of raising the status of the US 'consul general' to 'diplomatic agent and consul general' the consul in Beirut, William Gwynn called the idea 'premature' and ill-inspired. Similarly, Middle East expert William Westermann argued that the US should avoid recognizing the independence of Syria, which included Lebanon at that time; abide by the 1924 Convention which respected French rights in these territories; and avoid promoting its interests at French expense or separate Syria from Lebanon because such step was liable to have negative economic results. ${ }^{7}$ Naturally, those who believed that the US ought to have special rights in these countries tended to interpret the Convention's stipulations in a different way, insisting that US consent was necessary for any change in their status. ${ }^{8}$ Nevertheless, US officials tended to not to interfere in Syrian affairs. Thus, the deference which US officials demonstrated toward France had a considerable impact on their policy toward Syria and it explains their lack of firm commitments toward that country, except for defeating the Vichy forces.

5. Churchill to Roosevelt, Doc. 60, Roosevelt and Churchill: Their Secret Wartime Correspondence, Edited by Francis L. Loewenheim, Harold D. Langley and Manfred Jonas (New York: E.P. Dutton \& Co. Inc., 1975), 145.

6. Philip J. Baram, The Department of State in the Middle East 1919-1945 (Jersey City, NJ: KTAV Publishing House, Inc, 2009), 129-130.

7. Ibid, 132.

8. Cited in, The Chief of the Division of Near Eastern Affairs (Murray) to the Ambassador in France (Bullit), Washington, 13 January, 1938, Foreign Relations of the United States, 1938, Vol. II (United States Government Printing Office, Washington 1955), 1007. 
However, this policy changed considerably in November 1942, when the State Department gradually abandoned the Vichy-Washington connection and moved toward recognition of the independence of Syria and Lebanon. This was largely as a result the increasing aggression demonstrated by the Vichy regime. Seeing that US interests were under serious threat the State Department showed more willingness to support the independence of these countries. The fact that Vichy's usefulness as an intelligence source was declining and that the State Department was regarded by the liberal press as an appeaser brought the US decision makers to adjust their approach. Moreover, the feeling that it was urgent to act against France intensified in the eyes of those who did not wish to De Gaulle be the next to take the country, and the fact that Operation Torch which was aimed at expelling the Vichy forces from North Africa succeeded, emboldened the State Department to grant recognition to Syria and Lebanon. In addition, the nomination of two pro-Arab officials in the State Department, George Wadsworth who became consul general for Syria and Lebanon, and Philip Ireland who was nominated head of Middle Eastern research in the Division of Special Research accelerated and eased the adjustment process. By October 1942, the State Department became clearly more pro-Arab and less pro-French and the two countries were increasingly regraded as areas of "direct interest" to the US. ${ }^{9}$

In 1943, Roosevelt sent General Patrick Hurley who met members of the Syrian National Bloc and thereby recognized them as the country's legitimate leaders. At the same time, the US government regraded Quwatli as a strong leader capable of promoting its interests in the region and turned a blind eye to his past pro-Nazi sympathies. Not only did Quwatli cooperate with the US he also pledged support for the Allied war effort against Germany. In addition, Roosevelt planned to invite him to the UN Conference in San Francisco. The bilateral relations reached an unprecedented cordiality and when Roosevelt died the Syrian press was replete with articles praising him as the Arabs' great friend.

In 1943, the State Department debated the future of Syria and Lebanon. One of the ideas proposed as a solution was to establish a regional federation in which Syria and Lebanon become members and it called for promoting commercial relations between the US and the two countries. ${ }^{10}$ At the same time, pressure for greater US involvement came from people in the region. Both the Maronite and the Orthodox bishops of Beirut called for US intervention and Quwatli stated openly that he could count on US support in the struggle with France. ${ }^{11}$ Gradually, more officials became in favor of US intervention. Moreover, US State Secretary Cordell Hull's fear of an Anglo-French deal that

\footnotetext{
9. Baram, 133.

10. Ibid, 137.

11. Ibid, 138.
} 
would bar the US from entering these countries played an important role in accelerating the rapprochement with these countries. Finally, in August 1943 the State Department decided on a long-term policy toward Syria and Lebanon. The policy makers decided that France must leave and on September 19, 1944 the US finally recognized the independence of these countries. Several reasons led to this decision; the fear that the Soviet Union might penetrate the region; De Gaulle's delaying tactics and reluctance to grant recognition to these countries; the mounting resentment among Syria's politicians who sought to restore their position as founders and leaders of pan-Arabism and; the conviction in the State Department that since the US participated in the war it had the right to exercise influence in the Levant. ${ }^{12}$ Gradually, the conviction that France had no right to the Levant became rife in US government circles and when Loy Henderson became the director of the Office of Eastern and African Affairs in the spring of 1945, he insisted that France had no rights in the Levant. ${ }^{13}$ Consequently, the US government had fully supported Syria's position in its negotiations with France. In response to Jamil Mardam Bey's inquest regarding Washington's position, Hull said that the US fully supported Syria's right to conclude treaties with other countries as long as they are voluntarily and mutually reached..$^{14}$

President Harry Truman who came to power on April 12, 1945 adhered to Roosevelt's policy and continued to support Syria's aspiration for independence and when Quwatli informed him about the French bombing of the Syrian cities, which came after his refusal to grant France special privileges in his country, he appealed to De Gaulle to treat the country as a sovereign state. ${ }^{15}$ However, by the end of 1940s US officials made it clear to Quwatli that he was expected not only to facilitate the transfer of oil through its territory but also to reach an agreement with Israel.

While the upper echelons in the State Department tended to stay away from Syria and Lebanon the middle managers were in favor of intervention. Generally, however, the State Department sympathized with the grievances of the Arabs in these territories. At the same time, the Syrian people held numerous demonstrations calling for US intervention with supplies and even troops. The State Department's answer was generally positive and some

12. Ibid, 141-142.

13. Prime Minister Winston Churchill had noted on more than one occasion that "we had supported the attainment of freedom from French control by Syria and Lebanon." Prime Ministers' Meeting No. 3 of 1953, Meeting of Commonwealth Prime Minister, Secret, June 5, 1953; Cabinet Papers, 133/135. Cited in Martin Gilbert, Winston S. Churchill, Vol. VIII, Never Despair, 1945-1965 (Boston: Houghton Mifflin Company, 1988), 841.

14. Cited in, Salma Mardam Bey, Syria's Quest for Independence 1939-1945 (Reading, UK, 1994), 148.

15. Cited in, Memoirs by Henry S. Truman, Vol. I: Year of Decisions (Garden City, New York: Doubleday \& Company Inc., 1955), 242. 
officials such as Henderson and his supporters argued that Syria's request for military assistance constituted "excellent opportunity which we should seize at once." 16 The advocates of active policy in the Levant were highly encouraged by the faltering British economy which made it difficult for Attlee's Labor government to deal with this region. ${ }^{17}$

Direct US intervention in Syria did not take place until its independence and the beginning of the Cold War. It was at that time that the British government informed Washington of its inability to maintain forces in the region. At the same time, the CIA was entrusted with the task of searching for a Middle Eastern country capable of containing the Soviet Union. It was clear by then that the US was concerned primarily about the danger of losing access to the large Middle East petroleum deposits. Cold War considerations loomed large in Washington's decision to become involved in Syrian politics. According to CIA official Miles Copeland US objectives were to prevent a regional struggle from leading to war with the Soviets; to coax the regional governments into joining the free world and; to create an environment conducive to investments. When the heads of the CIA debated these issues, they looked for a country willing to establish a democratic regime. ${ }^{18}$ The consensus in the CIA was that Syria was the best place for such experiment since there were no British interests and no monarchy which could stand in the way. As it turned out, however, the first attempt to introduce free elections in Syria was utter disappointment for the CIA. ${ }^{19}$ Quwatli was reluctant to liberalize the political system. He was reluctant to reach a settlement on Palestine, refused to let the Arabian-American Oil Company (Aramco) install a pipeline on Syrian territory, and dismissed Washington's concern about the threat that the Ba'th party and the Communists posed to US interests. ${ }^{20}$ Consequently, the US government sought other means by which to protect its interests in the region and thereby antagonized the Syrian regime causing the bilateral ties to deteriorate virtually beyond repair.

\section{US Intervention and the Aborted Coup}

US support of Syria's independence led to cordial relations with the National Party while left-wing parties such as the SSNP (Syrian Social Nationalist Party),

16. Cited in, Baram, 147.

17. Ibid.

18. Miles Copeland, The Game of Nations: The Amorality of Power Politics (London: Weidenfeld and Nicolson, 1970), 37.

19. Copeland, 38-39.

20. Douglas Little, "Mission Impossible: The CIA, and the Cult of Covert Action in the Middle East," Diplomatic History, 28, no. 5 (2004), 670. 
the Arab Socialist Party, the Ba'th Party and the SCP (Syrian Communist Party) were regarded with suspicion. The US was particularly suspicious of the Communist leader Khaled Bakdash who capitalized on anti-US propaganda to come to power. Moreover, the fact that the SCP collaborated with Quwatli worried US officials and this was the main reason why the Congress rejected Quwatli's request for arms in 1947. When Quwatli rejected Washington's request to allow the Trans-Arabian Pipeline (Tapline), which passed through Syrian territory the bilateral ties deteriorated significantly and the tension reached its peak when Truman recognized Israel. Convinced that mending fences with Quwatli was no longer an option, US officials began considering the possibility of overthrowing him by encouraging Za'im to stage a coup.

Moreover, the fear that a Soviet-supported coup was a distinct possibility drove Washington to consider this option seriously and the CIA was ordered to contact Za'im. Miles Copeland, Ambassador James Keeley and the Military Attaché Major Steven Meade were the ones who took part in this operation. Meade met Za'im on November 30, 1948 and at least five times thereafter. When Za'im agreed to stage a coup, he requested that the US intervene by causing turmoil that would justify overthrowing Quwatli's government, or provide funds for that purpose. Although the US did not respond to his request Copeland promised that following the coup Washington would immediately recognize the new regime de facto and de jure a few days later. Finally, on March 30, 1949 Za'im arrested Quwatli, suspended the constitution and proclaimed a military dictatorship. Initially, Za'im demonstrated willingness to fulfill Washington's expectations. He improved his relations with Turkey and Israel, agreed to cooperate with ARAMCO and suppressed the Communists, arresting more than 400 of their activists. Seeing that Za'im kept his promises Washington recognized his regime on April 16, 1949.21 The State Department agreed to the plan but asked Meade to incarcerate the corrupt Syrian politicians, reorganize the government, introduce reforms and strive to resolve the Arab-Israeli conflict. ${ }^{22}$ However, there was no consensus among US officials regarding the prospect of turning Syria into a democratic state. Copeland and Meade were somehow optimistic, however, not everyone shared their view. While Jim Keeley believed that democracy could take root in Syria after a short interlude of dictatorship, Deane Hinton insisted that intervention would lead nowhere. He said, "I want to go on record as saying that this is the stupidest, most irresponsible action a diplomatic mission like ours could get itself involved in, and that we've started a series of these things that will never end." ${ }^{23}$ Indeed, his prediction materialized and Za'im who initially listened became autocratic and ignored the suggestions made by US officials. Although there is no conclusive evidence that the US initiated the coup, it certainly did not

21. Ibid, 671.

22. Copeland, p. 42.

23. Cited in, Copeland, 43. 
stop it, especially since Za'im agreed to sign the Tapeline agreement and start a dialogue with Israel as Washington requested. Generally, the US was pleased with the coup and recognized him as president. ${ }^{24}$ What becomes evident from Washington's attitude is that its main concern was that the Syrian regime was instrumental in supporting its wider objectives in the region such as promoting a solution to the Arab-Israeli conflict by absorbing a large number of Palestinian refugees, and providing easier access to the region's oil resources. In other words, Syria was not the main objective but rather what it could do to promote Washington's general desiderata in the region.

On August 14, 1949 another officer, Sami Hinnawi staged a coup but in turn was overthrown by Colonel Adib al-Shishakli who killed Za'im and became Syria's strongman for the next five years. Once again, the US sought to benefit from the political change in Syria hoping that the new leader would serve its interests in the region by remaining loyal to Western interests and containing Soviet penetration. Therefore, Copeland and Meade remained in touch with Shishakli and offered to train his security force. Shishakli impressed US officials who came into contact with him. He was regarded as a figure capable of promoting stability which could lead to economic growth and as a practical leader who was likely to agree to absorb a large number of Palestinian refugees without significant expenses to Washington. In a letter to the State Department the US ambassador to Iraq Burton Y. Berry noted that "Syria offers some promise," that "Shishakli has both personal authority" and that "Syria furthermore has greater opportunity for economic development as less cost and is only Arab country that could absorb large amount of refugees." 25 State Secretary John Foster Dulles felt that Shishakli was reliable and that Syria was capable of absorbing Palestinian refugees. ${ }^{26}$ Likewise, Assistant Secretary Henry A. Byroade was convinced that the solution to the refugee problem "required above all leadership such as the Syrian government was now providing." ${ }^{27}$ Shishakli capitalized on the trust which US officials had in him and played the role expected of him with consummate skill. Seeking arms from Washington he allayed its concern that they would be used against Israel, promising that he did not wish to push it into the sea, but he implored Dulles to send arms quickly to allow the Syrian army time to be trained in their use. ${ }^{28}$ So impressed was the

24. Moubayed, 81 .

25. The Ambassador in Iraq (Berry) to the Department of State, Baghdad, May 17, 1953, FRUS 1952-1954, Vol. IX, Part 1 (Washington D.C.: Government Printing Office, 1986), No. 31, 89.

26. Memorandum of Discussion at the 147th Meeting of the National Security Council, June 1, 1953, FRUS 1952- 1954, No. 137, 381.

27. Memorandum, by the Officer in Charge of Lebanon-Syria-Iraq Affairs (Funkhouser), Washington, November 15, 1952. FRUS 1952-1954, No. 520, 1057.

28. Memorandum of Conversation, Prepared in the Embassy in Syria, Damascus, May 16, 1953, FRUS 1952-1954, No. 23, 58, 62. 
Second Secretary of the US legation William D. Brewer that he wrote to the State Department, "his private recognition that Israel will be a factor in the area for a long time is gratifyingly realistic." Yet he was astute enough to realize that "Colonel Shishakli is concerned with the establishment of a modus vivendi rather than with a permanent settlement." 29

For a while it seemed that all was going according to the plan until Shishakli decided to turn to the Soviet Union for help. In December 1951, Truman agreed to declare Syria eligible for US military assistance, and on August 27, 1952 the legations in Syria and Lebanon were elevated to the status of embassies. However, in February 1954 Shishakli himself was overthrown in a coup staged by left wing officers and he was exiled to Lebanon. Meanwhile, Washington was left with the dilemma of responding to Syria's request for arms. In a letter to Secretary of Defense Charles Erwin Wilson, Dulles wrote that in order to ensure that arms provided to the countries in the region were used only for defense purposes there was need to make arrangements for joint military planning between the recipients and the US ,especially with regard to Iraq and Syria. ${ }^{30}$ When the debates regarding the need to establish a western defense organization in the Middle East officials in Washington saw considerable value in adding Syria to it. Once more, it became clear that Syria was regarded as serving a wider plan which the US had for that region. Consequently, it agreed to a military grant on the proviso that Syria participate in a defense pact that was being discussed at that time in Washington. ${ }^{31}$

As it turned out however, the negotiations regarding including Syria in the proposed pact did not go as well as expected. In a letter to the US embassy in Turkey from November 11, 1954 Dulles noted that "We question [the] practicality [of] endeavoring at this time [to] bring Syria into the defense picture. Also, because [of] limited appropriations we [are] not able [to] plan this time [to] allot any funds to Syria for military assistance." 32 This was especially the case since Shishakli sought the same amount of arms that was allocated to Turkey. ${ }^{33} \mathrm{He}$ also expected substantial amount of economic aid for domestic projects, insisting that he must receive enough to justify the political risk of signing an economic agreement with the US because, as he put, he will be criticized for "sellout to the

29. The Minister in Syria (Cannon) to the Department of State, Damascus, September 25, 1952, FRUS 1952-1954, No. 494, 1010-1011.

30. The Secretary of State to the Secretary of Defense (Wilson), Washington, September 8, 1953, FRUS 1952-1954, No. 151, 417.

31. Paper Approved by the Chiefs of Mission Conference at Istanbul, Istanbul, May 11-14, 1954, FRUS 1952-1954, No. 212, 512.

32. The Secretary of State to the Embassy in Turkey, Washington, November 11, 1954, FRUS 1952-1954, No. 236, 558. The parentheses are mine.

33. The Ambassador in Syria (Moose) to the Department of State, Damascus, November 6, 1952 FRUS 1952-1954, No. 510, 1045. 
imperialists." 34 For quite some time this concern prevented Syria from asking the US for economic assistance. In a paper by the Bureau of Near Eastern, South Asian and African Affairs from December 17, 1954 the author noted that "Whether in the face of the anti-Western popular mood in Syria, the present Government will have the courage to associate with the American 'imperialists' to the extent of accepting our offer of economic aid (made to Syria in September 1953) remains in doubt." 35

The archival evidence shows clearly that Washington welcomed Shishakli's to power. ${ }^{36} \mathrm{He}$ portrayed an image of a moderate leader willing to cooperate. This became evident when the president's envoy Eric Johnston was sent to the Middle East to discuss the distribution of the Jordan River's waters between Israel and its Arab neighbors. Shishakli responded favorably, agreeing to meet his American guest. However, when he turned to the Soviet Union for support the US no longer considered him a worthy ally.

When Bakdash became leader of the SCP and demonstrated hostility toward the US the bilateral relations took a serious turn for the worse and no improvement was in sight until 1961, and even the return of the pro-American Prime Minister Fares al-Khoury did not change that course. Khoury's resignation in 1955 left no hope for improvement when his successor Sabri al-Asali turned to the Soviet Union as well, leaving Husni al-Barazi as the only pro-American left in the Syrian government. Besieged by his critics and accused by pro-Nasser loyalists for being a CIA agent, he was in no position to improve the bilateral relations. He was sentenced to death in absentia and fled to Lebanon. ${ }^{37}$

Adnan Malki who came to power after Shishakli's removal in February 1955 began immediately by approaching the Soviet Union and thereby raised concern in Washington. To counter this danger US agents contacted Colonel Mahmoud Shawkat, leader of the SSNP who was in contact with the CIA for quite some time. Meanwhile, however, Malki whose ambition to become a 'Syrian Nasser' was assassinated on April 22, 1955 by the Alawite SSNP member Yusuf Abd alRahim who hoped for a right-wing coup. There were several speculations regarding the motives. Some argued that Abd al-Rahim was ordered to carry out the assassination by one of his superiors who held a grudge against Malki. Others attributed the assassination to Nasser's meddling in Syrian affairs but according to the State Department, Abd al-Rahim sought to take revenge on Malki who

34. Department of State Position Paper, Washington, May 5, 1953: U.S. Military and Economic Aid, [Tab 4], FRUS 1952-1954, No. 607, 1208.

35. Briefing Paper by the Bureau of Near Eastern, South Asian and African Affairs, Washington, December 17, 1954, FRUS, 1955-1957, Vol. XIII, Edited by John P. Glenon et al. (Washington D.C. Government Printing Office, 1988), No. 287, 514.

36. Moubayed, 88. Parentheses are in the text.

37. Ibid, 124. 
seduced his teenage daughter and became her child's father. ${ }^{38}$ US agents learned from pro-Western elements in the Syrian army that Malki planned to remove Shawkat and other officers connected with the SSNP from their positions. Malki's murder was regarded by many of his Ba'thist followers as a conspiracy by the CIA.

Recent classified documents confirm that US officials had been in touch with Shawkat and one should not discount the possibility that they were involved in the assassination, or at least that they were aware of the plan and did nothing to stop it. The upshot was that in the elections of August 18, 1955 Quwatli returned to the presidency. Seeking to portray an image of a moderate leader he asked the US to restrain the Saudis and the Egyptians but the State Department's response was that "it appears certain such remonstrances we might make would not significantly affect their behavior." 39 At the same time, he worked closely with the Ba'thists and turned to the Soviet Union for help. The rise of Nasser, Shishakli's downfall and the Israeli raid on Gaza which took place on February 28, 1955 had such impact on US popularity that virtually no one in Syria was willing to speak on its behalf. Even the hope that Quwatli would be in a position to improve the bilateral relations faded when he turned to Moscow for aid.

Quwatli's contacts with the Soviet Union caused much concern in Washington and brought the issue of supplying Syria with arms to the fore once again. Byroade opined that Syria should not receive arms in large amounts "as long as the Israeli situation exists." 40 This conviction clearly demonstrates that Washington had wider objectives in the region which the ties with Syria were designed to promote. Resolving the Arab-Israeli conflict and finding a solution to the Palestinian refugees loomed larger on Washington's foreign policy agenda and its officials sought a definite commitment on the part of the Syrian government to address itself to this issue and refrain from turning to the Soviet Union for aid. Hence the delay in the shipment of arms to Syria. Besides, there was considerable degree of distrust in Syria's intentions. US officials were not convinced that Syria's request for arms were genuine and that it only came as a tactic to pressure the Soviet Union to sell its arms at a bargain price as Herbert Hoover Jr. noted "It seems likely Syrian Government would merely use our offer for bargaining with Soviets." 41 Reluctant to forfeit the possibility of enhancing the bilateral relations the State Department faced a major dilemma; refusing Syria's

38. Christopher Solomon, "Revisiting the Malik Affair," Syria Comment, https://bit.ly/ 2OxuMdm, accessed April 23, 2017.

39. Telegram from the Department of State to the Embassy in Syria, Washington, February 6, 1955, FRUS, 1955- 1957, Vol. XIII (Washington D.C. Government Printing Office, 1988), No. 290, 517.

40. Memorandum of Conversation, by the Officer in Charge of Palestine-IsraelJordan Affairs (Waller), Washington, June 9, 1953, FRUS 1952-1954, No. 622, 1236.

41. Telegram from the Department of State to the Embassy in Syria, Washington, October 25, 1955, FRUS, 1955-1957, No. 313, 557. 
request could push its leaders to turn to the Soviet Union while sending arms without a commitment to solve that Arab-Israeli conflict could have adverse effect on one of Washington's major objectives in the region. The attitude of the US embassy in Damascus toward the Syrian request for arms was summarized in a telegram from October 6, 1955 which stated that "We do not wish compete with Soviet bloc in supply of arms but we do not wish impression to arise that US is not interested in helping its friends obtain requirements necessary for their defense." 42 Like most officials the embassy members opined that in order to prevent Syria from turning to the Soviet Union the US ought to respond favorably to the Syrian request. ${ }^{43}$

Despite their suspicion of Syria's aims US officials were less reluctant to provide Syria financial aid for domestic reforms. However, Syria continued to refuse US aid fearing the conditions attached to it. ${ }^{44}$ By refusing US aid Syria seemed acting as a recalcitrant country acting contrary to the US Mutual Security Act of 1955, which determined that any country receiving aid ought to agree to contribute to the defensive strength of the free world and capitalism. ${ }^{45}$ Despite US suspicion Syria's behavior was quite docile during that period. Its leaders did not act in an irresponsible manner and did not resort to nationalizing western companies. What stood on the way of better relations with Damascus was the fact that US officials became so entrenched in their own propaganda campaign regarding the sinister Communist penetration and the threat to the regimes in the region that they tended to see any contact with the Soviet Union as a threat that ought to be resisted by all means possible. Recently classified documents of the National Security Council based partially on reports received from the US embassy in Damascus during 1955-1956 shed light on the anti-Communist mood which prevailed in Washington at that time. Some of them are pertinent to quote. One report states, "Syria is at the present time the most wholeheartedly devoted to a neutralist policy with strong anti-Western overtones." Other reports attributes that change to the Palestinian problem, the frequency of the takeovers in Syria and the Communist penetration of the army. Some reports specifically targeted the left-wing parties as responsible for the grim state of affairs in the country. There were also reports with dramatic tone warning that there was a left-wing trend that posed a danger to the regime and that "If the recent trend continues there is strong possibility that a Communist-dominated Syria will

42. Telegram from the Department of State to the Embassy in Syria, Washington, October 6, 1955, FRUS, 1955-1957, No. 306, 546.

43. Memorandum from the Assistant Secretary of State for Near Eastern, South Asian, and African Affairs (Allen) to the Under Secretary of State (Hoover), Washington, December 8, 1955, FRUS, 1955-1957, No. 314, 558.

44. John C. Campbell, Defense of the Middle East: problems of American Policy (New York: Harper \& Brothers, 1960), 267-268.

45. William Blum, Killing Hope: U.S. Military and CIA Interventions Since World War II (Monroe, Maine: Common Courage Press, 2004), 85. 
result, threatening the peace and stability of the area and endangering the achievement of our objectives in the Near East." Finally, there was a report urging the government to "give priority consideration to developing courses of action in the Near East designed to affect the situation in Syria and to recommending specific steps to combat Communist subversion." 46 However, despite all these dire warnings there is no evidence anywhere in the documents that any of the leftist, Communists or any other group have done anything intended to harm US or Western interests in Syria or in the region as a whole. In fact, these were highly exaggerated assessments. The Syrians were essentially pragmatic without a tendency to infiltrate, penetrate or control. ${ }^{47}$ Nevertheless, US officials preferred to be misled by their own warnings. For example, the US ambassador to Syria James Moose, Jr., believed that a Communist-dominated Syria was liable to do substantial harm to American interests in Turkey and to NATO countries and stressed that it was essential to act before it was too late. At that time the Middle East entered a period of unusual unrest. Iraq and Britain aimed at plotting against both Syria and Egypt; the British exerted pressure on Washington to join the conspiracy and the CIA which for quite sometimes had been toying with the idea of overthrowing Nasser, agreed to leave him alone and instead was ready to contemplate an action in Syria. Encouraged by its recent victory in Iran where it managed to overthrow Muhammad Mossadeq's regime and restored Shah Muhammad Reza Pahlavi the US government seemed anxious to expand its influence in this petroleum-rich region. At that time Teddy Roosevelt's grandson Archibald aspired to become famous like his cousin Kermit who planned and executed the operation to overthrow the Shah and hoped that he could do something similar in Syria.

On January 8, 1956 a telegram from the embassy in Damascus stated that according to local press reports Shishakli had been in Syria and was plotting a coup with the SSNP and other Syrian officers. ${ }^{48}$ When Syria showed interest in moving in Nasser's direction the CIA was once again on alert and informed the government of the potential danger. Consequently, Dulles planned to overthrow the Syrian regime and make it look like a coup by "indigenous anticommunist elements within Syria". ${ }^{49}$ Seeking all the help and advice that they could get he and Eisenhower decided to discuss the matter with the British. However, the meetings took place at the precise moment when the British joined the French and the Israelis in the attack on Egypt following Nasser's nationalization of the Suez Canal in July 1956. During the negotiations it was decided to carry out Operation Wakeful (known to the British as Straggle) in order to prevent the rise of the

46. All quotes regarding the perceived Communist threat are cited in Blum, 85 .

47. Ibid.

48. Telegram from the Embassy in Syria to the Department of State, Washington, January 8, 1955, FRUS, 1955-1957, No. 318, 563.

49. Little, 675. 
socialist Ba'th party in Syria. According to some reports there was fragmentary evidence that the plan was to encourage the Druze to rebel and to ignite a border conflict with Turkey simultaneously. Referring to the coup attempt as Operation Wappen the CIA coordinated it with the intelligence services of Britain, Iraq, Jordan, and Lebanon. The decision to proceed with the operation was made in April 1957.

Participating in the planning was Wilbur Crane Eveland and several other US officials. At a meeting with Michail Bey Ilyan, one of Quwatli's associate, which took place in Damascus on July 1, 1956 Archibald Roosevelt asked how it would be possible to help the conservatives in Syria prevail over the Communists and their leftist supporters. Ilyan provided names of those who could help and recommended that the US take control of the radio stations and the newspapers in Damascus. However, Ilyan's warning that that the coup should not take place simultaneously with the announcement of the nationalization of the Suez Canal, which raised Nasser's prestige, led to its postponement to October 25, 1956. According to plan the Syrian army had to take control of Syria's big cities, including the borders with Jordan, Iraq and Lebanon; to place army units throughout Damascus, and to keep the members of the new government in the dark until the coup was over. ${ }^{50}$ Ilyan asked for a half million Syrian pounds which he promptly received. As it turned out, however, the operation had to be postponed again due to the Israeli invasion of the Sinai, which began on October 29, 1956. Eisenhower was disappointed by the delay. His concern about the oil supplies of the Middle East intensified his resolve to start the operation soon afterwards. When saboteurs blew up the British oil pipeline which passed through Syrian territory on November 3, 1956 he was enraged. He noted in his memoirs that he would have to consider implementing "a crash plan, drawn up months earlier, for shipping more oil to Europe."51 According to the plan Shishakli was to take over after the coup even though he was not regarded as the ideal candidate in the eyes of many officials. It was for that reason that Assistant Secretary of State for Near Eastern, South Asian, and African Affairs George V. Allen wrote to Dulles on June 27, 1957 that "we should bide our time and await developments before taking any positive position relative to his possible return to power. $^{52}$

According to the plan Shishakli was to be assisted by his former chief of security Colonel Ibrahim Husseini. The plan was to send Husseini secretly to Lebanon and then smuggle him through the Syrian border to meet Syrian CIA agents and provide assurance that Shishakli would take over after the coup. The

50. Blum, 86-87.

51. Dwight D. Eisenhower, Waging Peace 1956-1961: The White House Years (Garden City, New York: Doubleday \& Company Inc., 1965), 95-96.

52. Memorandum from the Assistant Secretary of State for Near Eastern, South Asian, and African Affairs (Allen) to the Secretary of State, Subject: Adib Shishakli and the Possibility of a Coup in Syria, Washington, June 27, 1956, FRUS, 1955-1957, No. 329, 581. 
persons involved in the attempted coup were the Second Secretary for Political Affairs Howard Stone, the military attaché Lieutenant Colonel Robert Molly, the Vice Consul at the US embassy Frank Jeton and another official named Arthur Close. Their plan was to convince the commander of the Syrian armor school to deploy his tanks throughout Damascus and collaborate with the plotters to topple the regime. At a meeting in Stone's house it was decided to pay the commander $\$ 3$ million for his cooperation. A contact was made with Shishakli and some embassy secretaries at his house to give the impression that the event was no more than an ordinary soirée, but when Stone and his agents arrived at the desk of intelligent chief Abdul Hamid Sarraj they were caught trying to hand in the money to the commander and expelled from the country. ${ }^{53}$ Stone, Molly and Jeton were all declared personae non gratae and expelled from the country. But Molloy was determined to retaliate; upon arriving at the Lebanese border he pushed his Syrian motorcycle escort off the road and shouted, "Tell Colonel Sarraj and his commie friends" that Molloy would "beat the shit out of them with one hand tied behind his back if they ever crossed his path again." 54 The response from Washington was a total denial that a coup attempt was ever made. An article in Time magazine from August 26, 1957 dismissed Soviet reports regarding the coup attempt as mere propaganda. ${ }^{55}$ The State Department denied the accusation and recalled its ambassador from Damascus. In an article published in the New York Times shortly afterwards the writer speculated about the reason for the Syrian accusation but it did not occur to him that the accusation might have been true and even Eisenhower said nothing other than that the Communists had taken control of Syria and the Soviets supplied it with arms. ${ }^{56}$ In a telegram from August 21, 1957 to King Saud the president argued that the accusation was "part of a slanderous campaign to distract attention from the actual Communist intervention that was going on." ${ }^{57}$ And when he wrote his memoirs he insisted that the accusation was a "propaganda attack on the U.S." 58

\section{The Aftermath of the Aborted Coup}

In August 1957, the relations between the two counties reached another one of its nadirs. The Assistant Secretary for Near Eastern, South Asian, and African

53. John Prados, Safe for Democracy: The Secret Wars of the CIA (Chicago: Ivan R, Dee, 2006), 163-164.

54. Cited in Blum, 88.

55. Ibid.

56. Blum, 89 .

57. Telegram from the Department of State to the Embassy in Saudi Arabia, Washington, August 21, 1957 FRUS, 1955-1957, No. 364, 646.

58. Waging Peace, 197. 
Affairs William M. Rountree send a memorandum to the Acting Secretary of State in which he noted that the Syrian Government was unfriendly to the US and that it was getting closer to the Soviet Union. He argued that this attitude manifested itself in blaming the US for an attempt to overthrow the regime and expelling its diplomats from the country..$^{59}$ Whether or not the US government's reaction to the events in Syria was out of proportion to the real danger will continued to be debated. However, the British who took part in the aborted operation remained convinced that such was the case. Commenting on US reaction to the Soviet infiltration of Syria, Britain's Prime Minister Harold Macmillan referred in his memoirs to the events in Syria saying, "Here we had the full, almost embarrassing, support of our American friends." He added that "our function proved, not to stimulate but restrain the impetuousness of the State Department, which was interpreting the 'Eisenhower Doctrine' with all the enthusiasm of recent converts," and that "In this evangelical mood, Dulles seemed ready and even anxious to consider measures which a few months before he would have denounced as shocking and immoral." 60 Commenting of the events in Syria in August 1957, Macmillan noted in his diaries that "The Americans are taking it very seriously and talking about the most dramatic measures--Suez in reverse." Describing what he felt about the American attitude he said, "If it were not serious (and really satisfactory) it would be rather comic." 61 Macmillan was highly critical of the coup attempt advising that the West should not confront Syria directly but act through Turkey and the rest of the countries sympathetic to it. ${ }^{62}$

The realization that Syria was regarded by the US as little more than a pawn in its Cold War contest with the Soviet Union for world domination was a disappointing blow to the leaders in Damascus. By the same token, officials in Washington were frustrated by Syria's apathy and lack understanding for US global strategic needs in the region. ${ }^{63}$ Thus the relations between the two countries continued to deteriorate. Washington continued to refer to Syria as a 'satellite' or 'quasi satellite' state and false reports were disseminated that Syria was receiving massive amounts of arms from the Soviet Union. Among those who questioned the government's propensity to exaggerate was the journalist Kenneth Love whose report stated that he travelled throughout Syria and found

59. Memorandum from the Assistant Secretary of State for Near Eastern, South Asian, and African Affairs (Rountree) to the Acting Secretary of State, FRUS, 1955-1957, No. 355, 632-633.

60. Harold Macmillan, Riding the Storm 1956-1959 (New York: Harper \& Row, 1971), 277-278.

61. Harold Macmillan, The Macmillan Diaries: Prime Minister and After, 1957-66 (London: Macmillan, 2011), 55. Parentheses are in the text.

62. Riding the Storm, 279.

63. J.K. Gani, The Role of Ideology in Syrian-US Relations: Conflict and Cooperation (New York: Palgrave Macmillan, 2014), 65. 
no evidence of such shipments and that no Communist coup had taken place. And when Eisenhower's emissary Loy Handerson was sent to the Middle East in August 1957, he did not have anything extraordinary to report. In fact, a Department of Defense memorandum written in June 1957, two months before Henderson's departure to the Middle East stated that "The USSR has shown no intention of direct intervention in any of the previous Mid-Eastern crises, and we believe it is unlikely that they would intervene, directly to assure the success of a leftist coup in Syria." 64

In early September 1957 the US sent arms to the moderate countries that it sought to protect (Jordan, Lebanon, Iraq, Turkey and Saudi Arabia). The Soviets reacted by sending arms to Syria, Egypt and Yemen. The Syrian government accused the US of sending warships and reconnaissance planes to Latakia where Soviet ships had recently arrived. Moreover, it blamed the US for encouraging Turkey to concentrate troops along its border. Eisenhower responded that he assured the leaders of Turkey, Iraq and Jordan of US aid in case of aggression by Syria. It is highly likely, as Blum argued, that the US was not as passive as Eisenhower described. One of the president advisers, Emmet John Hughes had mentioned how the Under Secretary of State Christian Herter, "reviews in rueful detail...some recent clandestine American attempts to spur Turkish forces to do some vague kind of battle with Syria." 65 It seems that the US was seeking an opportunity to somehow invoke the Eisenhower Doctrine as it appears from a study done later for the Pentagon, which stated that "in the 1957 Syrian crisis...Washington seem to seek the initial use of force by target." 66 Furthermore, US officials tried to bring Jordan, Iraq and Saudi Arabia to claim that they were threatened by Syria but they all denied that such threat existed. Consequently, Washington's noise about Syria's drift to the left lost much of its credibility and the New York Times reported that its reaction was exaggerated and out of proportion to what really took place. ${ }^{67}$

The US regarded Syria in the same way that it considered Lebanon; as country that deserved attention primarily for the role that it played in the Cold War contest with the Soviet Union. ${ }^{68}$ The events that followed did not help allay

64. Cited in Blum, 91.

65. Cited in Blum, 91-92.

66. Cited in Blum, 92.

67. Blum, 92.

68. This becomes evident when one explores the real reason why the CIA was ordered to interfere with the Lebanese legislative assembly elections in 1957. We learn from Wilbur Crane Eveland that the CIA director Allen Dulles paid \$25,000 to ensure that a pro-U.S. candidate comes to power. According to Eveland, Ambassador Donald Heath insisted on holding new elections in order to defeat hostile politicians and demanded that the pro-U.S. foreign minister Charles Malik participate in the campaign. Jonathan C. Randal, Going All the Way: Christian Warlords, Israeli Adventurers, and the War in Lebanon (New York: Vintage Books, 1984), 161. 
the mutual suspicion. When Syria and Egypt began talking about creating a merger the US government became concerned and there was even talk about a plan to assassinate Nasser. Reports appeared between July 1957 and October 1958 in the Egyptian and Syrian press that there were at least eight attempts by the US, Saudi Arabia and Iraq to assassinate Nasser. It is impossible to determine exactly what role the US played in these alleged conspiracies. The fear of an American coup attempt was undoubtedly one of the reasons for Syria's quest for a merger with Egypt. According to Deputy Director of the CIA, Charles P. Cabell, the Syrians were concerned about the growing Soviet influence and therefore called for a union with Egypt. ${ }^{69}$

The News about the merger talks between Syria and Egypt caused alarm in Washington and led the decision makers to consider the possibility of convincing Syria not to join. Apparently, US intelligence officers approached King Saud asking to pay Sarraj \$5 million if he agreed to call off the merger. According to the testimony of one CIA official Sarraj gave the bribe to Nasser. According to another report, Sarraj had been informed that the US knew about the plan and approved the merger. Not much is known about US machinations in this event however, Douglas Little's account of what transpired gives the impression that the CIA was involved in the effort to dissolve the UAR in September 1961.70 Ironically, one of Nasser's condition for the merger was that Syria disband its communist party, an objective that the CIA failed to achieve. ${ }^{71}$ Complicating the bilateral relations was Lebanon's President Camille Chamoun's charge that Syria and Egypt were supporting a revolt of anti-government rebels in his country. Eisenhower had no doubt regarding the veracity of these claims.

The tension in the bilateral relations reached another crescendo in 1960, when Nasser reiterated that Israel will not be allowed passage through the Suez Canal. In protest, the American longshoremen decided to retaliate by boycotting ships of the UAR. The Seafarers' International Union and the International Longshoremen's Association refused to unload the cargo of cotton from the Egyptian ship Cleopatra which arrived at New York harbor on April 13, 1960. Consequently, the UAR retaliated with an embargo of its own. American ships which arrived at UAR ports were not served. The boycott extended to all UAR ports and labor unions in many ports such as Latakia, Beirut, Tripoli, Aqaba, Kuwait, Rabat and Port Sudan joined it. ${ }^{72}$ As a UAR member Syria took part in the boycott and thereby brought the US government to consider the means of dissolving the union.

69. Eisenhower, 262.

70. Little, 682-683.

71. Blum, 93-94.

72. Mohamed Hassanein Heikal, Sānāwāt al-Ghālyān: Harb al-Thālāthīn Sanah, Vol. I (Al-Qāhirah: Markaz al-Ahrām lil-tarjamah wal nashr, 1988), 445-446. 
Direct action by the US government did not lead to the dissolution of the UAR and it was only by using its Saudi and Jordanian allies that it managed to do so. The UAR was dissolved by help from what the Egyptian Al-Ahram's editor and Nasser's confidante Muhammad Hassanien Heikal described as "the syndicate of kings" which included Saudi Arabia's King Saud and Jordan's King Hussein. King Saud later admitted to Nasser than he paid £12 million in the efforts to dissolve the UAR. The government of President Nazim al-Qudsi of the People's Party that the Saudi money helped install in power collapsed in early 1962, and some of its leaders were put to trial in what became known as the Dandeshi case. Dandeshi was a Syrian politician who was tried for treason. Documents surfaced during his trial that he and other politicians were in contact with CIA agents who were engaged in planning to overthrow the regime in collaboration with the Special Security Committee of the Baghdad Pact. ${ }^{73}$

On the eve of the Six Day War of 1967 the leaders of the Ba'th party which came to power four years earlier were panicking. They were convinced that other officers within their ranks were plotting against them and that the reactionary monarchs of Saudi Arabia and Jordan were planning to overthrow them with CIA support. Their fear intensified when the Ba'thi officer Salim Hatum conspired against them from his base in Jordan where he installed a clandestine radio, which called upon the Syrian people to rebel against their leaders. His colleague, Colonel Abu Talal 'Asali later told the Egyptian press that the US conspired with Saudi Arabia and Jordan and they supported Hatum in the attempt to overthrow the Syrian regime. On April 25, 1967 the army magazine Jaysh el-Sha'b published an anti-religious article portraying God as "an embalmed toy in the museum of history." The article triggered a furious response and a large demonstration led by Shaikh Hasan Habannaka forced the regime to react by force. When the demonstration was disbanded by the police Habannaka was arrested, two Saudi diplomats were accused of provoking the protest and the CIA was blamed for writing and disseminating the article. ${ }^{74}$ Meanwhile, the tension along Syria's border with Israel mounted. On the eve of the Six Day War the Soviet press reported that Israel concentrated forces on the Golan Heights. However, US President Lyndon Johnson dismissed the reports as inaccurate. Commenting on the events that preceded the Six Day War he said, "The spring of 1967 was an ominous season.... Tensions were rising in the Middle East as a result of increased Syrian harassment of Israel." ${ }^{\prime 75}$ Meanwhile, the conditions in Syria continued to deteriorate and the frequent coups persisted until 1970, when

73. Mohamed Hassanein Heikal, The Cairo Documents: The Inside Story of Nasser and His Relationship with World Leaders, Rebels and Statesmen (New York: Doubleday \& Company, 1973), 204-205.

74. Patrick Seale, Asad: The Struggle for the Middle East (Berkley: University of California Press, 1988), 115.

75. Lyndon Baines Johnson, The Vantage Point: Perspectives of the Presidency 1963-1969 (New York: Holt, Reinhart and Winston, 1971), 480. 
Hafiz Assad came to power and remained Syria's president for thirty years. But even after his coup the bilateral relations remained tense and complicated.

\section{Conclusion}

This essay analyzed the course of US-Syrian relations from the Wilson era until the Six Day War. It demonstrated how the US failed to capitalize on the robust beginning, which could have led to better relations. Excessive deference to French interest in Syria prevented the policy makers in Washington from establishing firm foundations that could lead to meaningful relationship. Syria never occupied a high place on Washington's foreign policy agenda. All contacts with Syria were made with different and wider objectives in mind. Wilson's early statements about cooperation with Syria remained mere slogans with little substance. US involvement in Syria during World War II was essentially to win the war and no one in Washington seemed interested in its unique culture or the value of establishing cordial relations with it. The impression that emerges from the documents of that period shows that Syria's importance to the US has been marginal. When Nasser came to power in Egypt and spread his pan-Arab message US policy was aimed at curbing his ambitions and Syria received little attention. During the Cold War Syria began to loom larger in US foreign policy but only due to its strategic location in the Middle East and it was primarily the fear of Soviet expansion which led to US interest in that country. The excessive preoccupation of US government officials with the Soviet danger prevented them from developing a robust and clear policy toward Syria. Moreover, the fact that US policy-makers were preoccupied with Cold War considerations led them to ignore the differences between Syria and Egypt. An analysis of US foreign policy in the Middle East clearly shows that Syria was always discussed in tandem with Egypt and Saudi Arabia and rarely did the US diplomats discussed it as an independent country deserving special nurturing. Furthermore, the linkage which US foreign policy makers made between Syria and the Arab-Israeli conflict stood on the way of better relations. Not only was Syria expected to reach an agreement with Israel but also to absorb a large number of Palestinian refugees. Furthermore, substantial pressure was applied on Syria to join an alliance with the US, avoid connection with the Soviet Union and promote capitalism. It seems that by using Syria as an instrument to protect wider US interests in the region such as containing the Soviet Union, securing access to oil, resolving the Palestinian refugee problem and combating pan Arabism, Washington had lost the opportunity to establish firm foundations for robust relations with that country. 


\section{Bibliography}

Baram, Philip J. The Department of State in the Middle East 1919-1945. Jersey City, NJ: KTAV Publishing House, Inc, 2009.

Blum, William. Killing Hope: U.S. Military and CIA Interventions since World War II. Monroe, Maine: Common Courage Press, 2004.

Bureau of Near Eastern, South Asian and African Affairs, Washington, December 17, 1954, FRUS, 1955-1957, Vol. XIII, edited by John P. Glenon et al. No. 287, 514. Washington D.C. Government Printing Office, 1988,

Campbell, John C. Defense of the Middle East: problems of American Policy. New York: Harper \& Brothers, 1960.

Copeland, Miles. The Game of Nations: The Amorality of Power Politics. London: Weidenfeld and Nicolson, 1970.

Denovo, John A. American Interests in the Middle East. Minneapolis, Minnesota: University of Minnesota Press, 1963.

Department of State Position Paper, Washington, May 5, 1953: U.S. Military and Economic Aid, [Tab 4], FRUS 1952-1954, No. 607.

Department of State to the Embassy in Syria, Washington, October 6, 1955, FRUS, 1955-1957, No. 306, 546

Eisenhower, Dwight D. Waging Peace 1956-1961: The White House Years. Garden City, New York: Doubleday \& Company Inc., 1965.

Oren, Michael B. Power, Faith and Fantasy: America in the Middle East 1776 to the Present. New York: W.W. Norton, 2007.

Foreign Relations of the United States, 1938, Vol. II. United States Government Printing Office, Washington 1955

Gilbert, Martin. Winston S. Churchill, Vol. VIII, Never Despair, 1945-1965. Boston: Houghton Mifflin Company, 1988.

Little, Douglas. "Mission Impossible: The CIA, and the Cult of Covert Action in the Middle East." Diplomatic History, 28, no. 5 (November 2004).

Hassanein Heikal, Mohamed. The Cairo Documents: The Inside Story of Nasser and His Relationship with World Leaders, Rebels and Statesmen. New York: Doubleday \& Company, 1973.

Johnson, Lyndon Baines. The Vantage Point: Perspectives of the Presidency 19631969. New York: Holt, Reinhart and Winston, 1971.

Mardam Bey, Salma. Syria's Quest for Independence 1939-1945. Reading, UK, 1994.

Memorandum of Conversation, by the Officer in Charge of Palestine-IsraelJordan Affairs (Waller), Washington, June 9, 1953, FRUS 1952-1954, No. 622, 1236.

Moubayed, Sami. Syria and the USA: Washington's Relations with Damascus from Wilson to Eisenhower London: I.B. Tauris \& Co. Ltd., 2012.

Randal, Jonathan C. Going All the Way: Christian Warlords, Israeli Adventurers, and the War in Lebanon. New York: Vintage Books, 1984. 
Seale, Patrick. Asad: The Struggle for the Middle East. Berkley: University of California Press, 1988.

Solomon, Christopher. "Revisiting the Malik Affair." Syria Comment, April 23, 2017. https://bit.ly/2OXuMdm.

Telegram from the Department of State to the Embassy in Syria, Washington, October 25, 1955, FRUS, 1955-1957, No. 313, 557.

Truman, Henry S. Memoirs by Henry S. Truman, Vol. I: Year of Decisions. Garden City, New York: Doubleday \& Company Inc., 1955. 